\title{
COMUNICAÇÃO, MOBILIZAÇÃO POLÍTICA E DIALOGIA NO INTERIOR DOS MOVIMENTOS SOCIAIS: APONTAMENTOS ACERCA DO MST NACIONAL
}

Guilherme Jeronymo Pereira Hernandes e Oliveira

\begin{abstract}
Bacharel em Comunicação Social com habilitação em Jornalismo pela Escola de Comunicações e Artes da Universidade de São Paulo. Trabalho realizado sob orientação do Professor Dr. Dennis de Oliveira.
\end{abstract}

\section{Resumo}

Este trabalho realiza uma investigação acerca das estruturas de comunicação nacionais do Movimento dos Trabalhadores Rurais Sem Terra e tece considerações sobre seus papéis e potenciais, em especial no que tange a participação direta dos assentados e militantes em tais mídias.

Palavras-chave: Comunicação Comunitária; movimentos sociais; dialogia.

\section{Abstract}

This work carries through an inquiry concerning the national structures of communication of the Movimento dos Trabalhadores Rurais Sem Terra and consider its papers and potentials, in special in what it refers to the direct participation of the seated ones and militant in such medias.

Keywords: Communitarian communication; social movements; dialogue techniques

\section{Resumen}

Este trabajo realiza una investigación acerca de las estruturas de comunicación nacionales del Movimento dos Trabalhadores Rurais Sem Terra y hace consideraciones sobre sus papeles y potenciales, principalmente lo que refere a participación directa de los asentados y militantes en estas medias.

Palavras-chave: Comunicación Comunitaria; movimientos sociales; dialogía. 


\section{Introdução}

O contexto de exploração da Comunicação Social no Brasil é marcado pela presença de serviços privados que atuam livremente ou por concessões (no caso das Rádios e Tvs) e, às vezes, com recursos públicos diretos (publicidade) ou indiretos (isenções ou políticas de incentivo). Nossa sociedade chega hoje ao que Ferreira (2006) classificou como "sociedades emancipadas", "às quais se atribuem políticas comunicacionais em consonância com expedientes como transparência, ética, liberdade de expressão, equilíbrio social e divisão de poderes”. Apesar das discussões atuais acerca do papel de TV e rádio públicos, assim como das concessões públicas de rádio e televisão, mesmo esta estrutura estatal segue o formato padrão de comunicação dos meios privados de difusão, não permitindo participação popular efetiva. As classes populares e movimentos sociais ficam, dessa forma e como apontam as pesquisas de Comparato (2001) e Lupion (2006), alijadas dos meios de comunicação social eletrônicos, principal forma de se chegar às massas. Além destes meios, desde 1998 está regulamentada no país a radiodifusão comunitária e educativa, capitaneada pelas emissoras estatais da Televisão Educativa (TVE). Há presença ainda de emissoras estatais que difundem conteúdos dos poderes Legislativo e Judiciário. Reforçando este quadro vale citar López Vigil, em trecho retirado do trabalho de Ferreira (2006):

\footnotetext{
"A pergunta é inevitável: Quem e quantos são os donos da palavra e da imagem na América Latina e no Caribe? A concentração salta aos olhos e ao ouvido: $85 \%$ das emissoras de rádio, $67 \%$ dos canais de televisão e $92 \%$ da mídia escrita pertencem à empresa privada. (López Vigil, 2002: 490)".
}

Levantamentos de movimentos de apoio à comunicação popular e comunitária e contra a concentração, como o Donos da mídia, ligado ao Fórum Nacional pela Democratização da Comunicação, e do coletivo Intervozes, que apóia a causa do Direito à Comunicação, dão números ao quadro de concentração dos meios em cerca de uma dezena de grupos econômicos, reforçando o quadro privado, e restrito, das comunicações no país, de forma que não iremos detalhar aqui.

Tomamos ainda por consensual a ligação dos movimentos sociais com o caráter reivindicatório de políticas públicas para populações carentes e/ou excluídas, desconsiderando sua efetividade ou lisura durante tal processo, muitas vezes atacadas pela mídia conservadora, conforme o noticiário de veículos como Carta Maior, Caros Amigos e Carta Capital frisa continuamente. Neste sentido, as estratégias e políticas de comunicação destes movimentos se constituem como resposta aos ataques desta mídia conservadora, composta por veículos privados que compõe o quadro citado até então.

A necessidade desta comunicação "responsiva" se constrói também a partir da estrutura base dos meios de comunicação, em especial os de caráter privado, que vem 


\title{
COMUNICAÇÃO, MOBILIZAÇÃO POLÍTICA E DIALOGIA NO INTERIOR DOS MOVIMENTOS SOCIAIS: APONTAMENTOS ACERCA DO MST NACIONAL
}

a ser o que Detoni classifica como modelo difusionista de comunicação, em anteposição a um modelo dialógico:

\begin{abstract}
"No modelo de transmissão difusionista, o fluxo de informações é unidirecional e ocorre, em geral, sem intervenção dos ouvintes, apesar do tom coloquial e intimista de algumas emissões. A audiência é vista como uma massa amorfa, com características generalizantes. A relação que se estabelece é entre uma entidade abstrata (a emissora) e o ouvinte médio, outra abstração. Os conteúdos tendem a confirmar as posições e os valores cristalizados, contribuindo para homogeneizar os comportamentos e ignorando as diferenças. As emissoras dependem da indústria discográfica e das grandes agências de notícias e trabalham com temas e formatos padronizados. Requerem altos investimentos e possuem uma administração vertical e centralizada. (Cf. AMAYO, 1992, pp.61-62)

Já a radiodifusão comunitária busca estabelecer uma relação horizontal e de troca, criando muitas oportunidades de participação individual e coletiva. Ela desafia a divisão tradicional entre comunicadores e donos de emissoras de um lado e ouvintes-consumidores de outro. Na rádio comunitária, o ouvinte se transforma em comunicador, não apenas porque ganha acesso ao microfone, mas principalmente, porque se envolve com a produção e o gerenciamento e passa a ser "sócio-proprietário" de um meio de comunicação. Ele tem a possibilidade de exercer os papéis de receptor ou emissor, alternadamente (Netherlands, 1999 a). Além disso, o público é visto como sujeito participante e não como mera fonte de notícias, e isso representa uma mudança substancial na relação da emissora com os ouvintes (GEERTS, van Oeyen, 2001, p.81)." (DETONI, 2004).
\end{abstract}

Vale ainda citarmos Lima (1981) que pontua trechos diversos na obra de Paulo Freire em que tal modelo de comunicação, não-dialógico, recebe críticas, ao que destaco:

\footnotetext{
“Comunicação (é) a co-participação dos sujeitos no ato de pensar... implica numa reciprocidade que não pode ser rompida. O que caracteriza a comunicação enquanto este comunicar comunicando-se é que ela é diálogo, assim como o diálogo é comunicativo" (FREIRE, 1973, in Lima, pág. 59, 1981)
}

Para melhor refletir acerca dos dados de López Vigil, talvez animadores posto que anteriores ao momento atual de fusões e concentração, que se desenha na atual crise econômica, vale atentar novamente para as reflexões de Comparato (2001), que coloca os Meios de Comunicação de Massa hegemônicos como instituições ligadas histórica e ideologicamente às oligarquias, portanto aos poderes hegemônicos estabelecidos na sociedade. A solução, apontada pelo autor, está na democratização da emissão, através da gestão popular dos meios, e encontra respaldo nas teorias de Agenda Setting. Tal hipótese, por sua vez, deixa em aberto a possibilidade de que as classes populares não têm sua própria agenda, suas próprias necessidades, expressos nos meios de comunicação de massa. $\mathrm{O}$ mesmo ocorre com a grande maioria dos movimentos sociais, em especial aqueles que, diferentemente do Movimento dos Trabalhadores Rurais Sem Terra (MST), não contam com estrutura de dimensões e alcance nacionais, construídos em décadas de atuação.

Nos movimentos sociais que conseguem estabelecer suas estruturas de comunicação, ou se utilizar de estruturas de outras instituições, e nos meios comunitários, 
se constituem espaços de manifestação de minorias ou grupos, e por consequência espaços de constituição de contra-hegemonias, essenciais à diversidade cultural e à valorização das culturas locais, rumando para o quadro participativo almejado por Comparato. Este estudo almeja entender como isto ocorre no MST, em âmbito nacional, na formação estruturas de comunicação que fogem ao meramente responsivo ou informativo e almejam o dialógico.

\section{Sobre a estrutura de comunicação do MST}

Da investigação que balisou este texto, cuja metodologia será trabalhada posteriormente, percebe-se que o MST constrói sua estrutura de comunicação e produção simbólica a partir de uma relação entre uma estrutura centralizada, ao redor da qual se articulam sua assessoria de imprensa (AI), seus meios de comunicação (Jornal Sem Terra, Revista Sem Terra, Site e Rádios), seus meios de formação (escolas rurais, centros de formação, brigadas de cultura) e sua rede de informação (dirigentes, militantes e colaboradores, políticos próximos, etc). Este trabalho focará no conjunto dos dois primeiros itens, mais afeitos a lógica e tradição das Ciências da Comunicação. Na direção do Movimento, o militante responsável pelo setor de comunicação é Miguel Enrique Stédile.

Na série de entrevistas realizada e no material pesquisado, fica patente a ligação histórica do Movimento com a comunicação, ainda em seus primórdios, antes mesmo de oficializar enquanto tal. Segundo relatam militantes, quando as famílias da Encruzilhada Natalino estavam cercados pelo coronel Curió, em 1983, isoladas, foi o jornal, então um boletim mimeografado, passado de forma escondida pelos bloqueios do exército, que fazia a comunicação de dentro para fora e de fora para dentro. Respondia, o jornal, ao isolamento que a mídia fazia do campo, angariando apoio a mobilização e trazendo informações de fora para a ocupação. O Jornal Sem Terra conta sua data a partir deste boletim, ao passo que a criação oficial do Movimento se deu em 1984. Ainda em 1984 foi criada uma rede de telex, que ligou os comitês nos diversos estados, aos poucos substituídos pelo telefax e pelo fax, usados para integrar os escritórios regionais e assentamentos. Entre 1986 e 1988 houve um esforço para estabelecer o uso do rádio, primeiramente junto a Rádio Aparecida, católica, e depois através de rádios comunitárias. Nas fileiras do Movimento, ainda no começo da década de 1990, se fizeram alguns dos primeiros esforços no uso de redes informatizadas pela sociedade civil no país, com o uso da rede Alternex, do Ibase, com apoio da equatoriana ALAI. Neste mesmo período surgiu a Revista Sem Terra, sistematizada em definitivo por volta de 1997.

O massacre de Eldorado dos Carajás e o IV Congresso do Movimento, em 2000, foram fundamentais para ampliar a articulação entre as esquerdas, o que passou a ser um dos direcionamentos do Movimento, e refletiu em suas estratégias de comunicação. Nesta época se constitui sua assessoria de imprensa. Neste século, os 


\section{COMUNICAÇÃO, MOBILIZAÇÃO POLÍTICA E DIALOGIA NO INTERIOR DOS MOVIMENTOS SOCIAIS: APONTAMENTOS ACERCA DO MST NACIONAL}

esforços por uma mobilização do campo político da Esquerda no país, marcado pelo processo de construção do Fórum Social Mundial, em suas diversas edições, levou ainda ao surgimento do jornal Brasil de Fato e da Rádio Agência NP, que até hoje contam com o apoio do Movimento. Na infra-estrutura de comunicação o MST utiliza e-mails, tendo a sua disposição o domínio @mst.org.br, telefones convencionais (fixos, celulares, etc) e a ferramenta Skype para chamadas interurbanas e internacionais.

Hoje o setor de comunicação é centralizado na direção do Movimento, e das decisões desta direção são direcionadas as ações dos militantes envolvidos diretamente neste núcleo no diretório nacional, em São Paulo, a saber: um assessor de imprensa, uma profissional que realiza clipping e revisão, duas editoras (uma para o jornal e uma para o site), um diagramador para o jornal, além de dois editores, um membro da direção e um revisor para a revista. Atuam ainda outros militantes, em tarefas de infra-estrutura e distribuição. Este esquema não inclui a rede de assessorias nos outros escritórios nacionais e estaduais.

Esta comunicação, classificada pelo assessor de imprensa do Movimento como uma comunicação que responde a demandas pré-existentes, tem duas funções principais, a de informar a própria base social do MST sobre questões de seu interesse, algo em torno de 120 mil acampados e 350 mil assentados, distribuídos em 23 estados e no Distrito Federal, e informar a sociedade sobre as demandas e interesses do Movimento. Tem portanto uma função de manutenção da unidade interna e de formação de uma base de atuação política.

A perspectiva desta estrutura centralizada é de contenção de danos, para tentar dialogar com a sociedade através de seus próprios meios de comunicação e através de "brechas" nos meios de comunicação da "imprensa burguesa", em princípio considerada desfavorável ao MST. Os meios do Movimento se destinariam a públicos diferentes dentro deste quadro maior de funções, a saber: o Jornal Sem Terra se destina predominantemente a comunicação interna; a AI atende estudantes, a imprensa de esquerda e é a porta-voz para a "imprensa burguesa"; o site é ferramenta de divulgação para a imprensa como um todo, formadores de opinião e público interno, e a revista tem uma função de formação de público qualificado e apresentação e propagação dos ideais do MST a um público de formadores de opinião.

O Movimento tem ainda dificuldade com mensuração da demanda e dos custos desta produção, assim como limites financeiros para sua reprodução e distribuição a base, chegando de maneira desigual aos assentamentos e acampamentos país afora. Essa distribuição é mais focada na militância (setores, brigadas, instâncias e cooperativas), que se torna referência, quase que uma instituição intermediária. Há outros desafios, além da distribuição, para que as mídias baseadas na palavra cheguem a sua base: a tiragem (para o jornal e a revista) e o analfabetismo, inclusive funcional, que 
limita o jornal, a revista e o site. O rádio é o meio que atinge uma quantidade maior de pessoas, e o mais aceito, na opinião dos militantes entrevistados.

Fora as estruturas centralizadas de comunicação, o setor existe também nos assentamentos e acampamentos, havendo, geralmente, dois responsáveis por ele, e se constituindo, portanto, em uma estrutura cotidiana para o Movimento. Esses militantes tem aí a função de comunicação em seu dia a dia, geralmente agindo como portavozes e "olhos" do Movimento, de uma forma que será sistematizada pelas estruturas de comunicação centralizada, da mesma forma que os responsáveis locais por setores como produção, saúde, gênero, educação, cultura, frente de massa e outros. Embora o ideal fosse que a estrutura estivesse presente e atuante, de maneira sincronizada com as estruturas centrais, em todo assentamento e acampamento, demandas e deficiências ou dificuldades locais fazem com que ou o setor não se estruture, ou não tenha contato constante, ainda que mediado pelas direções estaduais com a direção nacional. Para a formação desta rede qualificada de militantes, que além de fazer as vezes de porta-voz e de passar informações para a assessoria de imprensa é fonte direta do jornal e do site são realizadas oficinas de mídia, de acordo com a demanda dos acampamentos e assentamentos.

É interessante frisar, antes de ater nossa análise nos meios de comunicação em particular, que a integração entre a área de comunicação e a de formação não é sistematizada, hoje, além daquela com as outras áreas (de produção, infra-estrutura e articulação), embora haja participação de membros da editora e da Escola Florestan Fernandes na sugestão de pautas e nos conselhos editoriais da revista e do jornal, o que se repete para os outros setores, geralmente quando da existência de demandas concretas ou diretas, e não no dia-a-dia.

A assessoria de imprensa (AI), hoje realizada pelo militante Igor Felippe Santos, surgiu no Movimento, em nível nacional, no ano de 2003, respondendo a uma demanda reprimida que existia, em grande volume, ao menos desde 1996, e que não contava até então com atendimento sistematizado. Hoje está presente nos três escritórios nacionais, em São Paulo, Rio de Janeiro e Brasília, e há militantes responsáveis pela função nos sete escritórios estaduais, no Rio Grande do Sul, Santa Catarina, Paraná, São Paulo, Pernambuco, Alagoas e Bahia. Nos estados em que não há assessor o dirigente responsável pela comunicação geralmente assume a função. Esta rede realiza de duas a três reuniões por ano, além de se articular através de uma lista de e-mails interna, de caráter informativo, e do uso da ferramenta Skype e de telefone e fax.

Entre os papéis da AI estão: clipping; socialização das atividades do MST com a imprensa de esquerda; atendimento a jornalistas; sistematização das informações em São Paulo, que se torna espaço de monitoramento e inteligência; formação de canais de diálogo com a imprensa e com colaboradores; comunicação com a sociedade como um todo; diálogo com entidades, inclusive na atuação em apoio a eventos e na 


\section{COMUNICAÇÃO, MOBILIZAÇÃO POLÍTICA E DIALOGIA NO INTERIOR DOS MOVIMENTOS SOCIAIS: APONTAMENTOS ACERCA DO MST NACIONAL}

construção de eventos; atuação em contra-informação, inclusive através dos meios de comunicação do Movimento, como o site, o jornal e a revista.

As ações de clipping, chamadas de "Leitura e Conscientização da mídia", são feitas para a direção, para a rede (de militantes/colaboradores) e para a base, em caráter nacional e estadual, pelos assessores de imprensa. No nível nacional, é feita por uma profissional que não tem função direta de AI, e focada nos veículos nacionais (Folha, O Globo, Estadão e Valor Econômico). Além do clipping simples, coletando e enviando notícias que envolvam o Movimento ou a temática, se faz uma resenha (termômetro), bimensal, na qual se analisa a cobertura, geralmente para as reuniões da diretoria nacional. Nesta atividade, há dificuldade em acompanhar a mídia eletrônica (Rádio e TV). Duas vezes por semana é feito clipping de sites noticiosos.

Além das funções de AI, o setor participa semanalmente de reuniões com os editores do site e do jornal, eventualmente contando com participação dos editores da revista, na qual são definidas as estratégias de curto prazo em comunicação e as pautas e coberturas do site e do jornal.

O Jornal Sem Terra (JST), veículo mais antigo do Movimento, passa hoje por uma reestruturação, motivada por discussões contínuas. Conversei com Nina Fideles, então editora, e que hoje não ocupa mais a função. Outros referenciais sobre o histórico do jornal, e sobre a evolução do setor de comunicação e de seus debates, geralmente ligados aos congressos do Movimento, podem ser encontrados no trabalho de Andreuchetti (1994).

Hoje o JST conta com 16 páginas, e são impresso 20.000 exemplares, em periodicidade mensal. Seu conteúdo é focado em realidade nacional e em notícias dos assentamentos e acampamentos e para essa base, razão pela qual é tido como um veículo de caráter interno. Em sua divisão, desconsiderado o fornal das crianças Sem Terrinha, encarte de quatro páginas, conta hoje com quatro páginas culturais, a saber "Estudo", de análise de temas, "Lutadores do povo", com biografias de brasileiros ligados a processos de libertação popular, como Chico Mendes, na edição 292, "Balaio", que faz as vezes de agenda e uma contracapa, na qual há campanhas de divulgação e apoio ou pôsteres e imagens que remetem ao ideário socialista, defendido pelo Movimento. Em relação ao noticiário político há cinco páginas de "Realidade Brasileira", noticiário nacional, duas de "Estados", com notícias de assentamentos, acampamentos e mobilizações e uma de "Internacional". Há ainda duas páginas de entrevista, uma de capa e uma editorial, onde há espaço para editoriais do Movimento e cartas dos leitores.

O processo de construção de pauta se dá em discussões com o restante da comunicação nacional, semanais, e que envolvem pauta e dinâmicas do site e da assessoria de imprensa. Suas fontes estão geralmente dentro do Movimento, tanto na 
militância e direção quanto na base. Somente as entrevistas tendem a focar mais, e não somente, no Movimento, mas todas as editorias tendem a trabalhar temas debatidos no MST, ou pela imprensa burguesa sobre o MST. As pautas são construídas, portanto, em torno de temas afeitos à realidade deles (acampados). Para Nina, "o diálogo acontece em todos os espaços do Movimento", com preferência para as matérias enviadas pelas direções e/ou comunicação estaduais, que a editora caracterizava como "o coração do jornal". Estas contribuições buscam ainda respeitar a linguagem dos colaboradores, que muitas vezes não corresponde a linguagem jornalística. Não se exige, inclusive, o "lead", a estrutura fixa, e a edição busca alterar o mínimo possível o conteúdo enviado. Há participação, crescente, dos leitores, através de cartas, e-mails, e nos encontros do Movimento de comentários pessoais. Os espaços mais comentados são as sessões de "Entrevistas" e "Estudos". a editora frisou ainda "o cuidado de fazer um bom jornal", incentivando as participações e um olhar sem-terra, analítico sobre os acontecimentos, inclusive pela periodicidade, mensal, que não permite tratar questões factuais, embora haja demandas de pauta "temporais".

O jornal faz uma opção por trabalhar a "formação através da notícia”, buscando uma linguagem acessível a base do Movimento, embora não simplista. É utilizado também em alguns espaços de formação (espaços, nos assentamentos e em alguns acampamentos, para educação e cultura) da mídia como meio de estudo coletivo e de fomento a debates.

$\mathrm{Na}$ investigação acerca da Revista Sem Terra foi realizada entrevista com o editor Antonio Biondi e com o militante e dirigente Neuri Rosseto, também utilizadas no entendimento do histórico e constituição do setor de comunicação.

A revista surgiu entre o final dos anos 80 e início dos anos 90 - os entrevistados não precisaram a data. Buscava então um caráter analítico, de forma complementar ao JST. O projeto inicial previa uma revista de estudos e artigos, baseada em dossiês. O projeto, que durou dois anos, foi liderado pelo jornalista Alípio Freire. Após as discussões deste período, a revista surgiu como uma mídia que buscava levar o Movimento para a sociedade. Recebeu grande atenção o projeto gráfico da mídia, que buscava ser leve, agradável, e nos primeiros números se trabalhou com duas ou três cores (o militante não soube especificar), por economia. Ainda de acordo com Neuri, sempre foi vista como uma revista luxuosa, por seu projeto gráfico e editorial, e mantinha foco em assuntos centrais, em cada número. Realizada quase que inteiramente por militantes, enfrentou problemas sérios de regularidade. Pensada para ser bimensal, quebrava todas as datas de lançamento, o que dificultou criar uma identidade mais forte entre revista e Movimento e impossibilitou um trabalho com assinaturas. Apesar destas dificuldades, a direção sempre decidiu por continuá-la. Havia seções para a sociedade e para a base do Movimento, que eram importantes para dar acesso, por exemplo, a questões internacionais e culturais, não informadas na mídia de massas. Não é nítida, porém, a separação entre estes dois perfis. 


\section{COMUNICAÇÃO, MOBILIZAÇÃO POLÍTICA E DIALOGIA NO INTERIOR DOS MOVIMENTOS SOCIAIS: APONTAMENTOS ACERCA DO MST NACIONAL}

Aproximadamente em 2004 a revista foi reestruturada, quando o professor de jornalismo Hamilton Octavio de Souza (PUC-SP) assumiu a revista, enfrentando o desafio da regularidade. Houve dificuldades, especialmente econômicas, pois não havia fonte de assinaturas. Em 2007, com a jornalista Beatriz Pasqualino assumindo a edição se aprofundou o direcionamento de aproximar o Movimento da elaboração da revista, se identificando com o veículo. Para Neuri, no período de Alípio, a revista ficava quase fora do Movimento. De seu corpo editorial (conselho e equipe de produção) somente Neuri participava diretamente. Essa transição começou no período de edição de Hamilton e se consolidou com Beatriz. Desde meados de 2008, o jornalista Antonio Biondi assumiu a edição da revista junto com a colega, permanecendo a dupla na função até o momento. Há ainda um revisor na equipe. Hoje a revista é bimestral e conta com cerca de 60 páginas, sem problemas de continuidade e com alguns números especiais, para congressos ou para o Fórum Social Mundial, por exemplo.

Antonio relata que a revista conta com participação e debate de apoiadores e integrantes em sua confecção. Enquanto a reunião de pauta conta com uma média de cinco a sete pessoas, a do conselho editorial, crítica a respeito do material já produzido, tem de 15 a 20 pessoas. Os editores buscam criar uma aproximação entre estes dois grupos, dos quais participam, criando um corpo, uma lógica mais coesa. Além do trabalho ser realizado pelos dois editores, o que torna sua edição final mais equilibrada, é de Neuri a função de fazer uma espécie de ponte com o Movimento, através de sua direção. Também são realizadas sugestões de pautas e críticas por email, sugestões de foco e demandas para trabalhar o material, participação esta que tem aumentado nas duas últimas edições, uma das quais comemorativa dos 25 anos do MST.

Além da participação através da comissão de pauta e da comissão editorial, tem se ampliado o conjunto de colaborações e contribuições na feitura da revista, com matérias realizadas pela rede de militantes e colaboradores do Movimento. A identificação da revista com o Movimento ainda é considerada pelos entrevistados como insuficiente, e ligada também com a ampliação das dinâmicas de manutenção da mídia, financeira inclusive. O processo de ampliação destes debates e mudança da revista, porém, não chega, e de acordo com os entrevistados não tem como chegar neste momento, aos acampamentos e assentamentos. Tal aproximação, hoje, se dá com os públicos mais próximos, buscando se capilarizar com as assinaturas, e na ampliação do setor/rede de comunicação interna. Essa identidade de públicos, porém, ainda é pouco clara, e tem sido discutida constantemente pela direção nacional. A revista se liga, hoje, a diversos setores do Movimento, direta ou indiretamente, como a Escola Florestan Fernandes, a Editora Expressão Popular, o setor de Cultura e outros, e está consolidada. Há, porém, uma espécie de "leitor médio" na revista identificado. Não é a base dos assentados, mas os militantes mais "especializados", formados inclusive 
em suas escolas. Para Neuri a revista é pouco utilizada internamente, e, quando dela se utilizam, o fazem com funções na formação política interna. Sua grande utilidade é nas relações públicas, internacionais ou de divulgação nos estados. O militante a caracteriza como uma comunicação dirigida a potenciais interessados no Movimento e em suas pautas.

O processo de construção da pauta diz muito sobre a relação desta mídia com seus públicos. Conforme apontado, é um processo que envolve os editores, a direção e colaboradores, em duas reuniões (de pauta e do conselho, que amplia e discute os apontamentos da primeira), o que, para Neuri, a aproxima de sua base. Após a escolha das pautas, partem para sua produção o que Antonio caracteriza como uma rede de apoiadores do Movimento, cujos laços enriquecem muito a publicação. Quem escreve geralmente são intelectuais, integrantes do Movimento e jornalistas, com colaboração do Conselho Editorial na formulação e busca dos contatos, como no caso da entrevista com o historiador Eric Hobsbawn (maio/2009, número 50), ou da cobertura da conjuntura boliviana, realizada por repórter do Brasil de Fato. A revista é ainda, de acordo com os entrevistados, independente da grande imprensa para se pautar.

O espaço na revista é dividido entre os temas de política, economia e coberturas internacionais, que dominam a pauta, variando em páginas e temas tratados de edição a edição. Os demais temas, como o próprio Movimento ou Cultura recebem de duas a três matérias, geralmente contando com menos destaque. A utilização de colunas, antiga na mídia, foi reformulada. Antes dedicadas a um tema, mas com colaboradores que se revezavam, passarão a ser assinadas por colaboradores fixos, em sua maioria intelectuais.

A revista é distribuída através do correio e de distribuição por colaboradores do Movimento, a partir das 24 secretarias nos estados. A cota varia de estado para estado, geralmente dividida em proporção ao número de assentamentos. Uma cota da impressão fica com a secretaria nacional, tanto para o público dirigido quanto para encontros nacionais. A tiragem varia, em "edições especiais", e materiais avulsos, como cartilhas e propagandas, podem ser incluídos.

Entre os desafios e necessidades da revista, os entrevistados destacaram a necessidade de uma aproximação maior com o Movimento e o restante da equipe de comunicação, processo que tem se dado de forma gradual, com avanços positivos nos últimos meses. Destacaram ainda a falta de recursos fixos para a revista, até por dificuldades nas finanças do Movimento, que hoje a sustenta diretamente, o que tem sido estudado pelos editores e direção, e leva a necessidade de aumentar o conjunto de assinaturas, hoje somente quatrocentas. Outra questão foi levantada neste tópico: como a base não compra a revista, mas a recebe, doada, Neuri coloca a hipótese de 


\section{COMUNICAÇÃO, MOBILIZAÇÃO POLÍTICA E DIALOGIA NO INTERIOR DOS MOVIMENTOS SOCIAIS: APONTAMENTOS ACERCA DO MST NACIONAL}

que ela não se sente responsável por ela, por sua manutenção, com uma consequente utilização em formação. Há uma afetividade com o meio, mas não um sentido de pertencimento e de responsabilidade na construção. Seria o caso, talvez, de cada uma das 380 mil famílias ter uma assinatura, que poderia representar inclusive um momento de união entre os familiares com sua chegada. Outro desafio elencado foi o de aumentar sua utilização e conhecimento na sociedade, como um todo, e o de se tornar nacional em sua elaboração, pois é "muito pensada ainda em São Paulo". Para tal desafio, uma saída seria aproveitar o potencial dos apoiadores do Movimento fora do país, como por exemplo os militantes da Via Campesina, com um vasto campo de conhecimento e muitas possibilidades de colaboração.

Em entrevista com a jornalista e militante Jaqueline Nikiforos, atual responsável pelo site da entidade, o surgimento da mídia foi datado em 1997, passando por duas reformulações, e passa por uma terceira em 2009. A mídia tem, como principal característica, o caráter noticioso, sendo presentes ainda documentos e dados históricos do Movimento.

Quanto às características da mídia, em especial a caráter noticioso/ comunicacional, a entrevista chamou atenção para três focos presentes no noticiário do site, a saber: nas atividades do Movimento (ações; ocupações; despejo; atividades culturais e de formação); nas políticas públicas relacionadas à reforma agrária, na União e nos Estados; na "linha de frente" contra o agronegócio, em reportagens e notícias contrárias ao setor.

Predomina no site o uso da linguagem jornalística padronizada nas agências de notícias, com reportagens curtas (três a quatro mil toques), e atualização diária de cerca de cinco matérias por dia, sendo comum a utilização de materiais de veículos e agências de notícias de campos políticos considerados de esquerda. Há também a presença de reportagens e entrevistas mais extensas, ligadas a temas amplos, da realidade ou do interesse do Movimento. Em relação a este predomínio jornalístico, diz a editora que "talvez a gente não tenha achado uma linguagem melhor que a jornalística”. Tal linguagem busca ainda ser simples, elucidativa, necessária, por exemplo, para permitir ao público que desconhece questões como a nomenclatura do agronegócio. Jaqueline entende essa questão como um dos grandes desafios da comunicação popular: não tratar quem está lendo como um idiota, mas ajudar o leitor a entender a complexidade.

O trabalho do site é realizado pela própria Jaqueline, que acumula com as funções jornalísticas algumas funções de programação, divididas com outros militantes, que colaboram quando necessário. As informações utilizadas chegam como material de contra-informação, da assessoria nacional, e como material de informação de atividades, das assessorias estaduais, “que mandam muito material”. Há também 
materiais que chegam via coordenadores e dirigentes de setores, ou através de e-mail, de militantes ou de dirigentes estaduais. Raramente a jornalista vai a campo, ficando a apuração a cargo da militância ou da assessoria de imprensa. A pauta, oriunda destes materiais, reflete demandas internas e da imprensa de esquerda, muitas vezes em resposta à própria imprensa burguesa, e é consolidada nas reuniões semanais do setor de comunicação.

Em relação ao público do site, a editora o apontou como composto pela militância, por profissionais liberais em geral, que se interessam pelo MST, e pela imprensa, que, em alguns momentos, como nas jornadas de luta, é o primeiro público. O número de acessos de diferentes IPs varia, ficando, no período das jornadas, com uma média de 3500 a 4500 acessos por dia. Em época de pico, como nas jornadas dos meses de março e abril, chega a 8000 acessos dia. Em seu uso pela militância, o site atinge geralmente coordenadores e dirigentes, além daqueles militantes que estão realizando cursos ou que representam o Movimento em atividades internas e externas, como o contato com as massas, com a base dos acampados.

Além do canal de participação através da sugestão de pautas, o site conta com um mural de comentários que funciona "como um termômetro" e é lido pela área de comunicação. Mediado, este espaço de comentários não permite propaganda, conteúdos sem relação com o tema discutido ou agressões, embora publique discordâncias.

Além do caráter noticioso, o site tem uma área institucional, na qual é possível encontrar a história do Movimento e suas linhas de atuação, de acordo com a editora muito aquém das possibilidades e mesmo do que seria necessário, e que é importante que este conteúdo esteja lá.

No espaço do site há ainda acesso a revista e ao jornal, que tem parte do conteúdo colocado no site, além de áudios do programa Vozes da Terra (rádio). Isto reflete o entendimento, recente ainda, de que o site é uma mídia central, por seu poder agregador e seu caráter midiático, de acesso assincrônico e dependente, somente, do acesso a rede, podendo inclusive servir como apoio para as outras mídias. Deste modo, o site é também um multiplicador das mensagens do Movimento, permitindo, por exemplo, o acesso a militantes e interessados que não tenham como assinar a revista ou o jornal. O site também colabora, eventualmente, com reportagens utilizadas pelas outras mídias.

Quanto à reformulação em curso, foi feita a crítica de que o site é muito engessado, do ponto de vista técnico, dificultando o trabalho de edição e o uso de ferramentas de áudio, vídeo e imagem. Há uma necessidade, portanto, de modernizar seu design, a qual não iremos analisar detalhadamente neste momento. Pesa ainda o fato 


\section{COMUNICAÇÃO, MOBILIZAÇÃO POLÍTICA E DIALOGIA NO INTERIOR DOS MOVIMENTOS SOCIAIS: APONTAMENTOS ACERCA DO MST NACIONAL}

da linguagem de programação que será adotada, a Drupel, ser baseada em software livre, além de mais flexível, segura, com mais funcionalidades e um layout mais flexível, além de contar com uma ferramenta de buscas melhor.

O rádio é utilizado no Movimento desde a década de 1980. A primeira experiência, realizada entre 1986 e 1988, foi de transmissão de um programa na Rádio Aparecida. De acordo com o relato de Neuri a rádio tinha grande aceitação pelos camponeses por sua relação com a Igreja Católica, que no processo da Constituinte apoiava a bandeira da Reforma Agrária de maneira engajada, como não poderia ser diferente, considerando sua relação com as Comunidades Eclesiais de Base.

O momento seguinte, no começo da década de 1990, foi da preocupação e multiplicação das rádios comunitárias, pela plasticidade e facilidade que a mídia permite, pois, ainda de acordo com Neuri, $\mathrm{O}$ rádio é uma facilidade no campo, não te impede de trabalhar, não é impessoal. Foi realizada formação técnica, e chegou-se a cerca de 50 rádios, entre comunitárias, rádios poste e programas em rádios locais, especialmente nas regiões sul e sudeste. No começo dos anos 2000 produzia-se ainda o programa Vozes da Terra, para as rádios do Movimento, distribuído em CDs ou online. Hoje, o programa foi descontinuado, havendo porém interesse em reativá-lo. As rádios tiveram um descenso desde o começo da década de 2000, por dificuldades técnicas e entreveros com a fiscalização federal, mas assentamentos como o de Itapeva mantém rádios ativas, em número que o setor de comunicação não soube precisar.

Não sendo esta, naturalmente, a primeira incursão da Academia no Movimento, que tem inclusive sólida relação com departamentos das Faculdades de Educação e de Filosofia, Letras e Ciências Humanas da Universidade de São Paulo, chamo atenção para as anotações de Detoni acerca de um dos trabalhos focados em rádios comunitárias do MST, de Mariângela A. S. Torrescana:

\footnotetext{
“(...) ‘MST: um novo prefixo no ar’ (...) destaca o importante papel da rádio comunitárias Terra Livre, inaugurada em 1997 no assentamento Conquista da Fronteira, no município gaúcho de Hulha Negra, a 398 quilômetros de Porto Alegre, onde vivem mais de 700 famílias de agricultores. Segundo a pesquisadora, toda a estrutura programacional da rádio voltou-se para a prestação de serviços e para o debate sobre a luta pela terra, uma questão central para os assentados. 'Quase todos os espaços têm, como pano de fundo, a educação ou as suas estruturas pedagógicas, visando esclarecer sobre os mais diferentes assuntos, em especial os que transitam pelas questões agrárias (...) Por carecer de uma estrutura comunicacional eficiente e estar situada em local de distâncias consideráveis, a comunidade apropria-se da rádio, utilizando-a como instrumento de comunicação de troca, mas comunicação no sentido amplo. Muitas vezes, ela assume funções/ papéis do correio, do médico, do professor, do membro da família.' (TORRESCASANA, 2000: 9-10)."
}

\section{Rede e militância - comunicação orgânica no Movimento}

Além da importância individual das mídias e dos setores próximos, como 
a editora, as escolas nos acampamentos e a Escola Nacional Florestan Fernandes, chamou-me atenção nas investigações que resultaram nestes trabalhos a importância dada às redes, seja a interna, entre militantes orgânicos ao Movimento e membros da base em funções de direção, seja a externa, composta de militantes que se relacionam, apóiam e/ou ajudam em ações, em sua maioria dentro da legalidade e estrutura do Estado ou da comunidade internacional. Igor Santos, assessor do movimento, coloca, a este respeito, que é central o sentimento de identificação e pertencimento ao Movimento nesta rede, e que seu motor são os valores, princípios e formas do Movimento são o motor desta rede, e têm uma unidade em todo o país. Para Antonio Biondi, a rede de apoiadores do Movimento e seus laços ajudam muito a enriquecer as publicações. Este papel é ainda mais valorizado pelo Jornal Sem Terra, para o qual o envio de notícias pela rede interna do Movimento é prioridade na publicação.

Em um primeiro feedback deste artigo com a militância do Movimento que colaborou em sua construção, nas entrevistas, registramos ainda a seguinte fala: " $\mathrm{Na}$ parte em que você trata do envolvimento dos militantes com a revista, do uso dela para o público interno, talvez valha colocar que estamos em um processo crescente nesse sentido, com a revista ganhando espaço entre a base e os dirigentes, ampliando esses laços e se aperfeiçoando com isso. Entre nossa conversa e agora, as coisas avançaram nesse sentido - a última reunião do conselho editorial calcou-se muito nisso -, e talvez valesse colocar um olhar de perspectiva positiva a respeito".

Este papel centralizador da comunicação reflete a ideologia e identidade do Movimento. Para Igor, por ser a comunicação um instrumento do Movimento, uma ação do MST, enquanto Movimento social, reivindicatório, político e ideológico que busca lutar pela reforma agrária (contra o latifúndio), pela terra e pela transformação da estrutura da sociedade, sua comunicação, e suas mídias, refletem essa organização. A relação destes elementos (participação popular, ação da militância nos Movimentos e distribuição ampla a uma rede) são centrais na determinação de uma relação, que temos como hipótese que seja Dialógica, entre os meios e seus receptores.

\section{Dialogias, Comunidade e Ideologia}

Para refletir sobre os resultados desta pesquisa me valerei do princípio teórico da Dialogia, ampliado com as conceituação de Comunidade e Ideologia.

A Dialogia tomo a partir dos princípios expostos na introdução deste trabalho, e a complemento com conceitos advindos das pesquisas em Jornalismo. Em Medina, a base da dialogia na comunicação se apresenta na relação entre emissor e receptor presente na história comunicada, em sua completude ou em sua relação com o receptor e na relação que se estabelece entre jornalista e entrevistado. Quando esta relação é completa, e há reflexão e troca entre os participantes, é estabelecida a Dialogia. Creio 


\section{COMUNICAÇÃO, MOBILIZAÇÃO POLÍTICA E DIALOGIA NO INTERIOR DOS MOVIMENTOS SOCIAIS: APONTAMENTOS ACERCA DO MST NACIONAL}

que dentre os meios retratados todos tem, em maior ou menor escala ferramentas que permitam o diálogo, seja na construção das pautas e na produção das reportagens e notícias, seja em sua recepção, mas o limite da distribuição e, principalmente, de confecção deste material simbólico com a base do Movimento é grande, e impede o diálogo completo. Embora haja, nos meios, participação desta mesma base, ela não é efetiva. São meios internos ao Movimento, que sem uma política de ampliação em distribuição e cobertura, que demanda um investimento que o Movimento não tem condições de realizar neste momento, por falta de recursos humanos e financeiros, não poderão se tornar comunitários.

A opção, ao que parece, de contar com uma estrutura de produção simbólica que trabalha de dentro para fora do Movimento (com a assessoria, o site e a revista) é a de criar uma estrutura de difusão e diálogo com a sociedade externa, simpática ou potencialmente simpática ao MST, enquanto o papel de coesão interna é mantido por outras estruturas, citadas no item destinado aos limites deste estudo. É uma opção, justificável do ponto de vista político, lamentável para aqueles que gostariam de ver os potenciais de uma experiência em comunicação comunitária desta amplitude. Ressalvo que utilizo o termo Comunitária por falta de um mais preciso, para se referir a um meio interno, destinado a um grupo coeso ou que se pretende coeso, com origens assemelhadas e objetivos decididos em comum e por consenso. Uso do referencial de Detoni, em sua defesa dos meios comunitários como forma de garantir pluralismo de idéias e exercício de uma democracia efetiva, como referência:

\footnotetext{
Elas permitiriam a valorização do "local", o protagonismo do ouvinte que passa a fazer parte de um espaço em que fala e não apenas é destinatário da fala. O esquema canônico da comunicação E-M-R é visto em sua dinamicidade. Sobre essa comunicação responsiva, Bakhtin adequadamente assinala que: (...) nos cursos de lingüística geral (inclusive em alguns tão sérios quanto o de Saussure) aparecem com freqüência representações evidentemente esquemáticas dos dois parceiros da comunicação discursiva - o falante e o ouvinte (o receptor do discurso). Sugere-se um esquema de processos ativos de discurso no falante e de respectivos processos passivos de recepção e compreensão do discurso no ouvinte. Não se pode dizer que esses esquemas sejam falsos e que não correspondam a determinados momentos da realidade; contudo, quando passam ao objetivo real da comunicação discursiva eles se transformar em ficção cientifica. Neste caso o ouvinte, ao perceber e compreender o significado (lingüístico) do discurso, ocupa simultaneamente em relação a ele uma ativa posição responsiva: concorda ou discorda dele (total ou parcialmente), completa-o, aplica-o, prepara-se para usá-lo, etc.; essa posição responsiva do ouvinte se forma ao longo de todo o processo de audição e compreensão desde o seu inicio, às vezes literalmente a partir da primeira palavra do falante. (2003: 271).
}

Além da participação popular e da administração realizada por grupos estatais ou privados com fins públicos (não empresariais), os meios comunitários se diferenciam, ao menos no plano ideal, dos demais meios pelo que Detoni classifica como comunicação dialógica, em anteposição ao modelo difusionista, conforme apontado na Introdução desta. Nos meios estudados, pela opção de realizar uma comunicação para o público exterior ao Movimento, o caráter difusionista, ao menos aparentemente, predomina. Ressalva feita ao Jornal Sem Terra, que se volta para o público interno, 
e para a transição buscada pela Revista Sem Terra, que pretende se aproximar do público interno, e tem buscado realizar este caminho nos últimos anos. Complementamos a revisão conceitual colocando que trecho anteriormente grifado em Lima, e outros que não reproduzirei neste artigo, a comunicação, para Paulo Freire, somente é comunicação na medida em que é dialógica, do contrário tratando-se somente de difusão. Outros autores, como Bakthin, vão além, e dizem que toda mensagem é por essência dialógica, pois em sua emissão está prevista a resposta/necessidade do receptor.

O conceito de Comunidade, em Bauman (2001) a discute enquanto espaço de segurança e de liberdade, assim como enquanto espaço de exclusão do outro em favor de uma identidade coletiva, e em detrimento das identidades individuais - assim entendidas num esquema de conceituação liberal. Tomo este princípio por base para esta análise, e creio se aplique ao caso estudado no sentido de que se observa, nos meios de comunicação e estruturas de comunicação e de formação do Movimento dos Trabalhadores Rurais Sem Terra um esforço por criar uma concepção conjunta, uma identidade composta por um ideário construído - aparentemente de forma coletiva e horizontal, posto que direcionado por congressos internos e por uma direção eleita, e com participação aberta em seus fóruns e espaços públicos de discussão, como suas mídias internas. Afirmar, porém, o nível de democracia e coesão nesta comunidade não é possível na análise realizada, e nem é o foco pretendido nela.

Para reforçar esta análise e entrar no conceito da Ideologia, utilizaremos ainda os referenciais de Adorno e Horkheimer, na "Dialética do Esclarecimento", e através da leitura de Maar (2008) apreendemos que a Ideologia é categoria resultante de uma mistificação no processo de compreensão do mundo, através da Cultura, composta e estabelecida pelas instituições sociais, tais e principalmente a escola, os meios de comunicação e instituições comunitárias (igreja, assentamento rural, sindicatos, família, etc). Nesta mistificação, resultado do rompimento com a natureza, surge também a Cultura, e ambos os conceitos se imbricam. Em um dos capítulos da "Dialética", intitulado "Indústria Cultural: esclarecimento como enganação das massas", Adorno aproxima Ideologia e Cultura no sentido de quase sinônimos, a primeira como espécie de formalização da segunda, quase uma 'face semiconsciente' daquela (cfe Lastória, 2008), componente e composta pela sociedade - através de suas instituições, como tratado anteriormente - ao que Maar (pag.8, 2008) coloca: "Ideologia hoje é isso: sociedade que se instala como se fosse única”. A compreensão de Maar (pag. 7, 2008), derivada da "Dialética", interliga teoricamente os três conceitos, ao que ele completa: "Não há cultura inocente: essa parece ser a advertência fundamental de Adorno e Horkheimer, mas também de Benjamin e Marcuse”. Tomando esta linha teórica, começamos a entender a relação entre Cultura e Ideologia: ambas as categorias são subjetivas e compostas em diversos aspectos pelas diferentes representações de comunidade, e que formam e são reforçadas pelas instituições de comunicação de 


\title{
COMUNICAÇÃO, MOBILIZAÇÃO POLÍTICA E DIALOGIA NO INTERIOR DOS MOVIMENTOS SOCIAIS: APONTAMENTOS ACERCA DO MST NACIONAL
}

massa, em especial a mídia e a escola, mas também as academias diversas. Seu impacto formador deriva do apelo que têm para a pessoa e sua comunidade, e aí está seu poder de referenciamento e reforço de uma ideologia hegemônica. O impacto desta ideologia dominante é categorizado como Dominação por Adorno e Horkheimer, ao que Maar (pag. 8, 2008) coloca: "A dominação é, agora, presença imanente na cultura”. No caso específico do MST, em seus assentamentos, acampamentos e estruturas burocráticas, assim como em suas estruturas de produção simbólica, há uma Cultura e uma Ideologia próprias, derivadas de um sentimento de Comunidade, que por sua vez separa a leitura de mundo do Movimento daquelas realizadas por outros grupos sociais. Levanto ainda a hipótese de haver uma tensão entre a Ideologia do Movimento e a das mídias de massa hegemônicas, que, creio, pode ser melhor entendida a partir dos referenciais de Oliveira (1997), citando Bourdieu:

\footnotetext{
"Assim, os campos sociais são definidos pelas ações sociais semelhantes construídas a partir do contato, do diálogo, do enfrentamento, do aceitamento da ideologia burguesa e suas manifestações. Por isto, Bourdieu fala dos campos associados a um outro conceito, o de habitus que ele define como: 'um conhecimento adquirido e também um haver, um capital (de um sujeito transcendental na tradição idealista), o habitus indica a disposição incorporada, quase postural" (pág 191)
}

E ainda:

\begin{abstract}
"Com esta concepção, Bourdieu descarta a produção como o lugar onde se encontra a essência do sistema social. Explicitamente, ele critica o marxismo por ter esta concepção. Segundo ele, as divisões sociais são formadas a partir de suas representações, ou seja, à medida que classes e outros agrupamentos sociais tem mecanismos de representação, elas passam a ter existência como campos autônomos." (pág 194)
\end{abstract}

\section{Objetivo, metodologia e limites do estudo}

O objetivo deste estudo fora o de testar a hipótese de que as estruturas de comunicação dos movimentos sociais assumiam um papel diferenciado das estruturas de mídia padrão / difusionista ou das assessorias de imprensa padrão, tomando por base a estrutura de comunicação do MST, em âmbito nacional.

Para tal, optei pela realização de entrevistas abertas com os membros do Movimento que participavam do setor de comunicação, em especial aqueles que produziam e editavam material de mídia. Como metodologia para a realização das entrevistas, optei ainda por trabalhar com uma série de perguntas simples, a saber: qual o histórico da mídia / setor; qual a tiragem e público do veículo; como se dá a participação do público no veículo; qual a relação do veículo com a base do Movimento; qual a relação do veículo com a direção do Movimento; como se constrói e se avaliam as pautas do veículo. A partir destas perguntas base, abriram-se as entrevistas, variando de acordo com a necessidade e complexidade da mídia, assim como da disponibilidade dos entrevistados. Fica aqui registrada minha gratidão aos entrevistados, que se mostraram abertos às perguntas, pacientes com as ignorâncias deste pesquisador e 
dispostos a contar, apaixonadamente alguns, sua relação com a comunicação, o jornalismo e o Movimento.

Como referencial para as entrevistas, utilizei as bases de Imaccolata e Medina, presentes na bibliografia, além de referenciais presentes na tese de doutorado do orientador deste trabalho, professor Dennis de Oliveira, também presentes na bibliografia.

Como limites para este estudo, destaco a impossibilidade de realizar entrevistas com os assessores estaduais, pelo momento político em que o estudo foi realizado e pela impossibilidade de se trabalhar com uma quantidade maior de entrevistas abertas, pelo pouco tempo - cerca de seis meses - previsto no estudo e por limites pessoais de tempo e disponibilidade financeira deste pesquisador. Desta forma, não ficam claras as formas como chegam as mídias ao Movimento, seja à militância / direção, seja à base (acampados e assentados), não permitindo maiores assertivas a respeito do impacto direto destes meios, e de seu papel na formação de uma ideologia do Movimento.

Outro limite importante a este estudo se dá na falta de uma investigação acerca das estruturas decisórias e participativas do Movimento, assim como de seus outros espaços de produção simbólica e de formação de um ideário, como suas escolas rurais, seus centros de formação, suas místicas (dinâmicas de interação e discussão), sua editora e sua inserção em Movimentos políticos e partidos, e na relação existente entre estas instâncias e suas estruturas de comunicação e espaços de discussão internos.

\section{Considerações finais}

Ao final deste trabalho considero que esteja clara a existência de uma estrutura de comunicação organizacional efetiva e atuante no Movimento, que o sustenta e o compõe, permitindo sua atuação sincrônica e coordenada em suas estruturas de direção e para a sociedade, de forma semelhante a de outras instituições públicas e privadas. Esta estrutura é gestada desde o Acampamento em Sarandi, na Encruzilhada Natalino, um dos marcos históricos dos processos de luta que levaram ao surgimento do MST. Outros momentos, como o Massacre de Eldorado dos Carajás e os esforços pela mobilização do campo político da esquerda, como a ascensão e "amadurecimento" do PT ao poder, o IV Congresso do Movimento (2000), o surgimento da Consulta Popular e o processo de construção dos Fóruns Sociais Mundiais refletiram no próprio Movimento, que creio apresente uma função de comunicação intrínseca, que faz parte de sua organização e de sua forma de atuação política no espaço público da sociedade. 


\section{COMUNICAÇÃO, MOBILIZAÇÃO POLÍTICA E DIALOGIA NO INTERIOR DOS MOVIMENTOS SOCIAIS: APONTAMENTOS ACERCA DO MST NACIONAL}

Há, porém, limites da integração entre as estruturas de comunicação, no que tange a inserção das demandas comunicacionais dos acampados, portanto caracterizando um processo comunicacional não dialógico, ou que poderíamos arriscar conceituar como de dialogia parcial, com presença de elementos difusionistas e dialógicos. Não há, portanto, participação direta dos acampados do Movimento na construção da maior parte destes produtos informativos. Se constata, ainda, confluência entre as estruturas de comunicação, ideológicas e formativas, sendo a área estratégica para a formação de uma "Cultura" Sem Terra, em especial considerando as dinâmicas contemporâneas do processo político e as disputas que o compõe.

A partir, especialmente, da análise do papel das estruturas de comunicação interna e de assessoria de imprensa coloco minha compreensão de que a comunicação é uma atividade meio para o Movimento, uma estratégia que se vale da produção simbólica para chegar a seu objetivo fim, que seria, numa análise weberiana, o poder, ou o projeto político de poder e sociedade, ideológico e subjetivo portanto, do MST. Um desafio seria talvez integrar esses meios de comunicação a sua base, permitindo que este jogo de poder seja mais direto e orgânico, e que esta participação reflita e transforme as dinâmicas que envolvem essa base. Tal mudança permitiria que fossem democráticos, como talvez não o sejam em nenhuma outra instituição, campo ou parte da sociedade, mas demandaria um nível de investimento e comprometimento que hoje nos parece irreal.

\section{Referências bibliográficas}

ADORNO, Theodor W.; HORKHEIMER, Max. "Dialética do Esclarecimento: fragmentos filosóficos". Rio de Janeiro: Jorge Zahar, 2006.

ANDREUCHETTI, Katia C. M. "A Imprensa do Movimento dos Trabalhadores Rurais Sem Terra: Um Estudo de Caso". Rio Grande do Sul: Universidade do Vale do Rio dos Sinos (Trabalho de conclusão de curso), 1994.

BAUMAN, Zygmunt. "Comunidade: a busca por segurança no mundo atual”. São Paulo: Jorge Zahar Editor, 2001.

BOSI, Alfredo. "Cultura Brasileira, Culturas Brasileiras" in: "Dialética da Colonização". São Paulo: Cia das Letras, 1992.

CANCLINI, Nestor Garcia . "Culturas híbridas: estratégias para entender e sair da modernidade”. São Paulo: Edusp, 1997.

"As Culturas Populares no capitalismo". São Paulo: Editora Brasiliense, 1989.

COMPARATO, Fábio Konder. "A democratização dos meios de comunicação de massa" in: "Revista USP", $\mathrm{n}^{\circ}$ 37. São Paulo: USP, CCS, 2000-2001.

DETONI, Márcia. "Radiodifusão comunitária: baixa potência, grandes mudanças? Estudo do potencial das emissoras comunitárias como instrumento de transformação social”. Dissertação de mestrado. São Paulo: Eca/USP, 2004. 
FERREIRA, Gisele Sayeg Nunes. "Rádios comunitárias e poder local: estudo de caso de emissoras legalizadas da Região Noroeste do Estado de São Paulo". Dissertação de mestrado. São Paulo: Eca/Usp, 2006.

FREIRE, Paulo. "Pedagogia da Autonomia: Saberes necessários à prática educativa". São Paulo: Editora Paz e Terra, 1999.

GONÇALVES, Bruno Lupion. "Marcos regulatórios e democratização da mídia: O direito de antena". Trabalho de Conclusão de Curso na Faculdade de Direito da Universidade de São Paulo. São Paulo: 2006.

HABERMAS, Jürgen. "Conhecimento e Interesse". Rio de Janeiro: Guanabara, 1987.

LASTÓRIA, Luis Calmon Nabuco. "Uma nova economia psíquica ou mutações tópicas Elementos para reflexão acerca da subjetividade contemporânea" in: DURÃO, Fabio Akcelrud et al. "A Indústria Cultura Hoje”. São Paulo: Boitempo, 2008.

LIMA, Venício Artur de. "Comunicação e Cultura: as ideias de Paulo Freire”. Rio de Janeiro: Paz e Terra, 1981.

LOPES, Maria Immacolata Vassalo de. "Pesquisa em comunicação". $8^{a}$ Edição. São Paulo: Edições Loyola, 2005.

MAAR, Wolfgang Leo. "Prefácio" in: DURÃO, Fabio Akcelrud et al. "A Indústria Cultura Hoje”. São Paulo: Boitempo, 2008.

MARTÍN-BARBERO, Jesús. "Dos Meios às Mediações: Comunicação, Cultura e Hegemonia". Rio de Janeiro: Editora UFRJ, 1997.

MEDINA, Cremilda. "Entrevista, o diálogo possível”. São Paulo: Ática, 1986.

OLIVEIRA, Dennis de. "Imprensa Sindical, Globalização Neoliberal e o Mundo do Trabalho”. Tese de doutorado. São Paulo: ECA USP, 1997.

\section{Webgrafia}

Constituição Federativa do Brasil - promulgada em 5 de outubro de 1988. Disponível em: https:/www.planalto.gov.br/ccivil_03/Constituicao/Constitui\%C3\%A7ao.htm

EPCOM, Instituto de Estudos e Pesquisas em Comunicação. “Os Donos da Mídia”. Porto Alegre: 2002. Disponível em: www.fndc.org.br.

Página do Movimento dos Trabalhadores Rurais Sem Terra. Disponível em: www.mst.org.br 


\section{ANEXOS}

\section{Relatório de atividades de pesquisa e produção}

Discente: Guilherme Jeronymo Pereira Hernandes e Oliveira

Docente responsável: Prof. Dr. Dennis de Oliveira

Título da monografia: "Comunicação como elemento de mobilização política e dialogia no interior dos Movimentos sociais - investigação e apontamentos acerca do MST Nacional”

Data: 23 de março de 2009, no Celacc

Atividade desenvolvida: apresentação do tema a ser pesquisado, sob orientação do Prof. Dr. Dennis de Oliveira.

Data: 31 de março de 2009, no Celacc

Atividade desenvolvida: Delimitação do objeto, com alteração do objeto inicial.

Data: 13 de abril de 2009, no Celacc

Atividade desenvolvida: Entrega de primeira versão do projeto ao orientador, com devolutiva da metodologia.

Data: 27 de abril de 2009, por e-mail

Atividade desenvolvida: Envio da última versão do projeto ao orientador.

Data: 13, 20 e 27 de maio de 2009, na sede do MST

Atividade desenvolvida: Entrevistas com membros do movimento.

Data: 08 de junho de 2009, por e-mail

Atividade desenvolvida: Orientação acerca da metodologia, com o orientador.

Data: 22 de junho, no Celacc

Atividade desenvolvida: Encontro presencial, com orientação acerca dos critérios de análise acerca do material pesquisado.

Data: 28 e 30 de junho, por e-mail.

Atividade desenvolvida: Envio de primeira e segunda versões da monografia.

Data: 6 de julho 
Atividade desenvolvida: Entrega da primeira versão, com devolutiva.

Data: 03 de agosto de 2009, no CJE-ECA.

Atividade desenvolvida: Entrega de segunda versão, com devolutiva.

Data: 17 de agosto de 2009 e-mail

Atividade desenvolvida: Entrega de terceira versão, com devolutiva.

Data: 14 de setembro de 2009, no Celacc.

Atividade desenvolvida: Discussão de referenciais para análise dos dados coletados.

Data: 26 de setembro de 2009, no CJE-ECA.

Atividade desenvolvida: Entrega de última versão, com devolutiva. 